This item was submitted to Loughborough's Research Repository by the author.

Items in Figshare are protected by copyright, with all rights reserved, unless otherwise indicated.

\title{
The politics of the digital technoscape in Turkey: Surveillance and resistance
}

\section{of Kurds}

PLEASE CITE THE PUBLISHED VERSION

https://rowman.com/ISBN/9780739191194/Digital-Transformations-in-Turkey-Current-Perspectives-in-

Communication-Studies

\section{PUBLISHER}

(c) Rowman and Littlefield. All rights reserved.

\section{VERSION}

AM (Accepted Manuscript)

\section{LICENCE}

CC BY-NC-ND 4.0

\section{REPOSITORY RECORD}

Celik, Burce. 2019. "The Politics of the Digital Technoscape in Turkey: Surveillance and Resistance of Kurds". figshare. https://hdl.handle.net/2134/25304. 


\title{
The politics of the digital technoscape in Turkey: Surveillance and resistance of Kurds
}

\author{
Burçe Çelik
}

\begin{abstract}
This paper explores how the state employs digital technologies in its pacification of dissident political bodies, subjectivities, and communicative capabilities. It explores strategies of resistance to the surveillance practices which come to the fore as a state form, as a means of social control, and as a mechanism for creating manageable and disciplined crowds. Drawing upon ethnographic data, it focuses on the contemporary politics of the Kurdish movement in Turkey. In particular, it analyses the digitized surveillance and resistance of Kurds, both of which function as crucial components of contemporary power regimes in Turkey.
\end{abstract}

Keywords:

This article explores the novel ways in which the use of digital technologies has become a political power in Kurdish-Turkish relations. Relations between the two communities have historically been shaped by two forces: On the one hand, there is the Kurdish insurgent nationalist movement, including groups like the armed PKK (Partiya Karkerên Kurdistan, or Kurdistan Workers Party) and its urban representative the KCK (Koma Civakên Kurdistan, or Group of Communities in Kurdistan). This movement claims to fight for the cultural and political rights of Kurds, including the official recognition of Kurds as a unique cultural group and the free exercise of their cultural identity and language in state institutions. On the other, there are the pacification regimes of the 
Turkish state, which regards this movement as a major threat to the territorial and political status quo in the region (Kirişçi, 2004; Özoğur, 2004). The objects and targets of the contemporary form of power employed against this movement are the political bodies acting and speaking for it, their political subjectivities, and their communicative capabilities.

This new form of power makes use of digital technologies in two paradoxical and related ways: As a state form, it captures the flow of information, colonizing the physical and cognitive spaces of bodies in their daily practices and communications through preemptive, decentralized, and routinized digital surveillance. In this form, the new power feeds off the juridical and police systems where collected data has become evidence to support accusations of involvement, support, or sympathy for terrorism in the counterterrorism trials of thousands of Turkish citizens. As a form of resistance, on the other hand, such power enables the rupture of control over information networks, provoking a new language to emerge that both negotiates and resists the all-encompassing colonization of communication. Significantly, Kurdish activists have been using digital technologies, and particularly the Internet, to produce effective critiques of these trials and the preemptive surveillance, and to continue generating new discourses and representations, asserting their ethnic and political identities. While neither attempts to control the Kurds nor their resistance take place only in digital spaces or through the application of information technologies, these technologies have provided a new rationale for both state control and for Kurdish resistance. When all public spaces have shrunk due to the prevalence of electronic surveillance, such technologies have created new communicative spaces.

This study attempts to show that the Turkish state has become a truly technological surveillant state in relation to dissident politics. While this tendency is not limited to the state approach to the Kurdish movement, it is enacted on Kurds most forcefully. The wider literature on the new forms of power tends to focus on surveillant states in western societies and overlook how surveilled people negotiate and resist these practices in their daily lives. Therefore, this study aims to contribute to the literature by discussing the ways in which the surveilled bodies, and particularly the Kurds, experience, manage, and resist the new forms of power in practice, in their daily lives, and in their political activities.

In what follows, I will first engage some of the relevant theoretical literature on modern and postmodern forms of control and resistance, 
outlining both the ways in which new control regimes operationalize their power on surveilled bodies and the immanent potentialities of resistance that can arise in the forms of resisting counterpublics. I then briefly contextualize the evolving political situation within the history of Kurdish-Turkish relations, before presenting an analysis of ethnographic research completed in 2012 with forty users of communication technologies in different cities in Turkey. I will suggest that technological forms of surveillance contribute to the colonization of bodies' communicative practices by inhibiting ordinary language, shrinking the boundary between public and private space, and distorting the intimate relationship between users and their digital devices and social media. In response to this, resistive politics aim to gain control of the means of communicability, particularly through the use of social media to create new languages, new selves, new modes of speech, and new sites of discussion and exchange that not only address Kurdish users but also nonKurds who are unfamiliar with the Kurdish reality. Finally, in the last part, I will sketch an outline of the contemporary authoritarian regime of Turkey's technological surveillant state and the resistance politics of digital young Kurds. This dynamic, I will suggest, also informs the Gezi movement of 2013 that has become one of the most diverse revolts of young people, including Kurds, in the history of Turkey.

Understanding Surveillance and Resistance in Contemporary Societies Recent studies on surveillance show that there is an intrinsic link between the digitization of information, the ubiquitous use of information technologies by citizens/consumers, and the unprecedented level of recording, storing, and manipulation of information by those with access to the data (Deleuze, 1992; Lyon, 2004). As bodies are immersed in digital spaces through the exposure and use of credit cards, electronic IDs, cellphones, telephones, the Internet, city cameras, and data-mining systems, they leave traces as they move, act and communicate within the fluctuating and flexible networks. Hence, the monitoring facilities and possibilities provided by digital technologies amplify the state's capability of control, giving rise to concerns about the maintenance of democracy and civil rights and the rise of new forms of authoritarianism (see Best, 2010; Morozov, 2011). Gilles Deleuze defines this new form of society that is administered and managed through computer- ized systems of surveillance as the "society of control," in which mecha- nisms of command become ever more fluid and immanent to the social field, distributed throughout 
the bodies of citizens/consumers who are no longer individuals (corporeal bodies) but dividuals "consisting of modulations of coded information,' (Bogard, 2007) internally divided into measurable and adjustable pieces, or data. For Michael Hardt and Antonio Negri (2000), in this new social formation that they call "imperial society" the relationship between power and the individual is "open, qualitative and affective," the social production of subjectivities is not limited to places, and power is everywhere and nowhere, generating "non-places" where the social production of subjectivities becomes a "fluid processes of the generation and the corruption of subjectivity" (p. 196). In such an environment, "The indefiniteness of the place of the social production corresponds to the indeterminacy of the form of the subjectivities produced"(ibid).

Technological control partakes in these subjectification processes, generating a simulated version of surveilled bodies; an additional self, (Poster, 1990) or data double, (Haggerty and Ericson, 2007) of pure virtuality, whose narrative is necessarily different from reflection of an original referent due to the technological mode of its representation (Best, 2010; Ball, 2005). The representation and re-creation of bodies in scanscapes are used for a variety of tasks within increasingly dominant modes of management of financial, ecological, and security risks (Lyon, 2007). In particular, law and technology function relationally in discriminating against sections of the population on the basis of (vague) definitions of terrorism, regarded as one of the greatest threats to contemporary societies. While anti-terrorism laws codify those who may be surveilled, the actual practice of surveillance generates evidential data of different versions of the lives (or crimes) of the surveilled completely outside their control (ibid). As Kirstie Ball (2005) suggests, surveillance is not only understood as information or knowledge but also as protection from threat. In order 
for the state to justify the prevalence of surveillance of selected bodies, it also needs to maintain both synopticism, (Mathiesen, 1997) or the communicative machines of fear and panic through which viewers and/or spectators are conditioned to believe in the deadly threat of terrorism in their society, and panopticism, (Foucault, 1977) or the imprisonment of bodies carrying the risk of terrorism and their exclusion from public spaces of action and communication (Ball, 2005: 94). Thus, in contemporary societies, digital surveillance enables the broadening and tightening of the net of regimentation around mass and individual bodies (Lyon, 2007: 170; Marx, 2007: 83). It therefore does not replace but rather consolidates existing forms of synoptic and panoptic control.

These global trends in the increasing control of citizens/consumers lead to local investment in centralized civil registry systems, digitized remote listening, advanced filtering systems, data mining systems, and city cameras. In this way, Turkey has now become a technological surveillant state which makes use of all these facilities to monitor its population, and particularly its dissident political subjects (Arslantaş-Toktaş et al., 2012; Topal, 2005). Importantly, Turkeys current counterterrorism laws are based on an extremely broad definition of terrorists acts, including non-violent, discursive actions which criticize or demoralize the security forces. In fact, according to the Minister of Internal Affairs, such actions may even include "poetry, painting, daily columns and articles"(Reporters withoutBorders, 2012). This enables the pervasive and manipulative surveillance of all dissident groups, resulting in thousands of people being put in prison and on trial as terrorist suspects. Technology plays an important role in gathering suspicious documents or conversations as such technological evidence creates the perception of precision, valid- ity, and reliability in the eyes of the public. Moreover, technologies are represented as truth production machines as they become evidence in counterterrorism trials and the source of discrediting messages about political subjects in media coverage. The pressure and lack of autonomy that journalists face in the contemporary mediascape as well as the 
crisis of the juridical system in terms of providing the basis for justice contribute to the operations of the new pacification regime that aims to "tame the social, political and economic forces" (Masoud, 2011 cited in Tüfekçi and Wilson, 2012) in seemingly democratic but essentially authoritarian ways.

My analysis of this new form of power is based on Michel Foucault's (1977) argument that possibilities of resistance are immanent within forms of power. If there is no place outside regimes of control, as Hardt and Negri (2000) argue, we should look for modes of resistance in all non-places. The digital technoscape is a non-place where one is subjected, willingly or not, to fluid regimes of control and subjectification. Yet, such fluidity not only contributes to forms of control but also to the interruption of control through the creation of a spatio-temporal gap between the surveilled and surveillor and the anonymity of users who actively partake in meaning from within the flexible and fluctuating networks of digitized power. Disruption of control of a limited duration and scope only carries the potential of resistance if the meaning-making process differs from the dominant ways of addressing individuals or the public. Digital communication technologies have no force separate from the social systems through which discourses and meanings are produced and shared across different social groups over the network at high speed (Stone, 1996).

Interpellation into the usership of the net (and thereby consent to be-ing surveilled) is based on the promise that an ordinary individual may become an active produser (producer and user, see Grinnel, 2009) of the self, language, and textual representation in the virtual presence of others in ways impossible in face-to-face relations. Although there is always an original referent to all virtual bodies on these platforms, each and every user that is present on the web of virtual relations and spaces is recreated in artificiality. The artificiality that is produced in the performative uses of the net within the work/ play of self-design (Groys, 2008) reveals both the limitations and potentialities of self-creation; limitations such as the digital divide, and the hierarchies that subsist between races, ethnicities, gender within the virtual spaces, and potentialities such as the renewal of speech and diction to create, recreate, and present the self that one finds in virtual social relations. As Hardt and Negri (2000) write, "Once we see ourselves for the simians and cyborgs we are," we must participate in "the continuous constituent pro-ject to create and re-create ourselves and our world" in the domain of artificiality (p. 92). 
This creation and re-creation of selves and worlds that we inhabit within the digital technoscape can be best understood with Michael Warner's (2002) concept of counterpublics. For Warner, "counterpublics are publics," produced through circulatory discourses, addressing diverse people, including strangers, hailing them into particular positions, "providing a sense of active belonging that masks or compensates the real powerlessness of human agents in capitalist society"(p.81). On the other hand, the difference of counterpublic discourse is that it "remains distinct from the authorities" and has a "critical relation to power"( Sheridan etal,, 2012: 101). The counterpublic does not conflict with power simply because it comes to the fore as a reflection of subculture or oppositional identities formed elsewhere, but precisely as the re-creation of languages, discourses, and subjectivities that challenge the dominant groups, ideas, and policies, as well as the speech genres and modes of address, that constitute the pub- lic. The potentialities of counterpublics are always immanent in public organizations that have the necessary tensions, perversities, and ambiguities to function continuously.

Functioning as a container for millions of users, (see Sofia, 2000 for the conceptualization of container technologies) the Internet becomes a social laboratory in which users can interact with each other through their representations and improvise circulatory discourses. Among Kurds searching for means of communicability and new ways of expressing or recreating themselves through a novel language and discourse that degrades power, disciplinary institutions, and the dominant political culture, such possibilities of the Internet contribute to the formation of a counterpublic. The Kurdish counterpublic is not solely instituted through online discourses; it has intertextual relations with all critiques of state authoritarianism, media synopticism, power relations, and dominant discourses that aim to create defeated, accepting, and docile consumers/citizens out of the Kurdish population.

\section{The Kurds of Turkey}

Kurds constitute the largest nation in the world without a state, and they struggle for their cultural and political rights in countries where they reside. The Kurds of Turkey have been in ongoing revolt against the political project of the Turkish Republic, which aimed to develop a nationhood based on the Turkish language and an imagined national identity that required a break with religiosity, local traditions, and non- Turkic ethnic identities (Yeğen, 1999; Özoğur, 2004). At first, Kurdish resistance against this establishment had the characteristics of local armed nationalist and religious rebellions, but later gained the traits of a wider, modern, leftist, pacifist nationalist movement in the 1960s and 1970s (Kirişçi, 2004). With the rise of the armed movement of the PKK in the early 1980s, ethnic and cultural consciousness grew and spread amongst almost all Kurds living in Turkey (ibid). Violence 
and human rights violations against Kurds during the military dictatorship of 1980-83, prohibition of the use of Kurdish both in private and public spaces, and the clearance of villages in the south eastern parts of Turkey under the State of Emergency Rules of the 1990s provoked many Kurds to become involved in activism and even join the armed struggle (Gambetti, 2009: 45).

For millions of politically active Kurds, the use of media technologies has become of crucial significance, signifying the possibility of deciphering human rights violations against Kurds, re-inventing themselves in a desired form, and producing a sense of nation in the absence an officially recognized Kurdish territory. After the newspaper Özgür Gündem and the satellite TV-channel MedTV were established in the 1990s, they became extremely popular in Kurdish populated areas, and were conse- quently treated as engines of terrorist propaganda by the state; journal- ists were killed, readers/viewers were arrested or exposed to the violence of security forces (see Hassanpour, 1998; Gambetti, 2009). After these bloody years, a relatively freer environment was established due to both the capture of the PKK leader in 1999 and the democratization processes adopted as a result of Turkey's aspiration to become a member of EU in the early 2000s. These changes did not put an end to the war between the PKK and Turkish army, but permitted the representation of Kurdish voters in municipalities and the Parliament with a distinct political party, and, to a certain extent, the presence of Kurds in media and creative industries.

The Kurdish diaspora has employed desktop and electronic publishing to develop a standardized Kurdish as well as an archive of extensive literature, both of which aim to produce a sense of belonging to a culture, literature, and history (Romano, 2002; Ayata, 2011). Likewise, Kurdish cinema and music became a means for Kurds to assert their cultural and ethnic identity more strongly than ever through digital media.

In this relatively freer environment, the government initiated the "Kurdish opening" in 2009, based on a political understanding of giv-ing "individual cultural rights to Kurds," including permitting the home- coming of PKK militants, opening of Kurdish language courses, and establishment of a state-run Kurdish-language television channel (Yeğen, 2013).

However, these developments have instigated national hysteria, with the Turkish public feeling it had conceded "enough already"(ibid). Meanwhile, politicized Kurds remain dissatisfied and continue to demand a neutral definition of citizenship that would not exclude their ethnicity and guarantees of the free exercise of Kurdish identity, including the use of their mother tongue for education and legislation.

Particularly after 2011, as the uprisings in the Arab World were spreading to different countries across the Middle East, the Turkish state reverted its strategy from providing individual cultural rights to a hard-line approach whose aim seemed to be to "finish off the PKK," 
cutting the organic links between the Kurdish masses, the PKK, and the pro-Kurdish political party (BDP). While this new tactic included traditional military operations against PKK militants, it focused more on the judiciary and police system, which tried thousands of people under anti-terror legislation, as well as on the propaganda machine and the media, which attempted to discredit the politicians of the BDP. As a consequence of this new political strategy, more than twelve thousand people, including Kurdish politicians, journalists, students, doctors, and even mayors, are on trial accused of aiding, abetting, or being a member of the KCK. The evidence in these trials mostly consists of data collected through digital surveillance methods. This research takes up the effects of policies regarding KCK cases and the pacification regime of the state towards the Kurdish population between 2009 and 2012. In 2013, the Turkish state once again adopted a relatively moderate approach, launching an apparent "peace process" to attempt to resolve the Kurdish conflict with constitutional reforms after an agreement with the PKK leader that PKK guerrillas withdraw from Turkish territory. However in 2014, the political climate has radically changed once more into which the peace process is fundamentally threatened by the clashes between the Turkish security forces and the political Kurds demonstrating against the inactivity of Turkish government with regards to the ISIS invasion of Kobane (the Kurdish area in the northern Syria).

The data

The data is derived from in-depth interviews conducted in 2012 with forty users of communication technologies, including telephones, cellphones, or the Internet, in İstanbul (17), Diyarbakır (9), Ankara (2) and Mardin (4). The sample focused on middle class Turkish (5) and Kurdish users, between 18 and 65 years of age, including digital activ- ists (mostly 18-40), university students, lawyers, teachers, intelligence officers, NGO workers, and the unemployed. The reason for the inclu- sion of Turkish users in the sample is to understand the comparative effect of technological surveillance on Kurdish subjects at a comparative level where the generalized surveillance also affects others. The sample focused largely on the middle class, because particularly Kurdish users of personal digital communication technologies and social networks tended to be middle class. The sample included twenty men and twenty women.

The in-depth interviews, which lasted an average of one-to-two hours, asked whether interviewees felt that they were being surveilled, how they reacted to such surveillance practices, and how they negotiated and/or resisted these forms of control. While some Turkish informants seemed to be less interested in politics, all my self-defined Kurdish in- 
terviewees were politically conscious subjects. Indeed, defining oneself as a Kurd is already a political statement in the political landscape of Turkey. Regardless of their level of involvement with a political party or organization, all informants were well aware of the current surveillance practices of the state. Most of them expressed concern that they were potentially/actually under surveillance and irritation at the infringement of their privacy. And yet, when the issue came down to the perceived risk of being under constant surveillance, there seemed to be differences between politically active informants and others, and between Kurds and Turks.

All digital activist interviewees use smart phones with a connec- tion to the Internet-by now ubiquitous gadgets among different social classes in Turkey. All of them were regular users of Facebook (the most visited page in Turkey) ${ }^{42}$ and some of them were also Twitter users. Those respondents experienced in virtual politics participated in forum discussions and contributed to urban-dictionaries and open blogs, and were truly members of the user publics of the digital ecologies. Those residing in Istanbul and Ankara had more heterogeneous crowds of vir- tual friendship networks that did not require offline acquaintances or kinship, and all of their personal messages became public as they wrote in their personal pages or open/closed Facebook groups, Twitter hash- tags, and blogs. As the centralized technological surveillance of the state tends to use telephone conversations, texting and email exchanges to record conversations or find/fabricate images as evidence, most of the users interviewed preferred to use social media sites like Facebook and Twitter for their cultural and political communications, as such sites have policies requiring the Turkish state to officially apply to access us- ers' private information. Despite Facebook being regarded as less trust- worthy in this sense due to certain groups being closed by the company after complaints by other users, it remains the most popular platform, providing users access to bigger and more heterogeneous crowds. 
The production of control and its effects

Turkey's surveillance regime is not a new phenomenon. The novelty lies in the growth of technological authoritarianism that amalgamates the forces of law, the police, and technology to produce digital materials that can be easily manipulated to generate fake conversations, fabricated images, and misleading narratives of crimes when there exists no rational way to prove the crime. Although one cannot argue that all evidence presented in the indictments of anti-terror trials is based on the technological mutation of non-evidence of crimes, lawyers, human rights associations, and civil right activists have concrete concerns about the way technological control functions to manufacture crime. One lawyer of a KCK case in Diyarbakır explains his experiences in such trials:

The indictments start with hundreds of pages of KCK history, continue with few testimonials of hidden witnesses, followed by hundreds of pages of transcriptions obtained by remote listening, transcriptions of wiretaps, text messages, and so on. All of these are read out in court. So the private lives of all these suspects are heard by everyone $[\ldots]$ The court becomes like a gossip show [...] since none of this information can be used to prove a crime on a rational basis, the prosecutors claim that they are encrypted messages.

There are many examples of such "evidence" in the indictments: An SMS message reading "37 B Black," sent from a suspect to her sister, asking her to buy a bra in this size and color, was interpreted by the prosecutor as code for a bomb. A telephone conversation during which a Turkish professor is invited to a meeting by another KCK suspect and responds "inshallah," interpreted as the conscious admission of participating in the terrorist organizations' meetings. A police photograph of 
an illiterate old Kurdish woman at a protest in Diyarbakır was claimed to be evidence that she was a KCK organizer, responsible for inviting protestors to the violent protest by email. Despite the fact that almost half of the wiretappings are in Kurdish, and have to be translated into Turkish to serve as evidence, these terror trials are often blocked by the denial of Kurdish suspects requests to testify in Kurdish. In the face of such evidence, suspects' lawyers often express feelings of desperation. As one lawyer in Diyarbakır said, "I do not know how to defend them," or, as another from Mardin expressed it; "I feel as if I was given a role to play in an absurd comedy; a sort of deadly joke."

The effect of surveillance on the surveilled bodies becomes pressing, as people feel the constant pressure of being relentlessly watched in their daily activities and communications. A female municipal worker, on trial without detention accused of helping the KCK without being a member, explains this effect:

When you are taken into custody, they put on the table all the information they have collected over time without your knowledge [...] It's terrifying to see. I mean, it's as if I was always naked. And the way they present all these things in indictments! All the pieces are sewn together to create another you. The data is yours, but the story is not. What is most terrifying is not my possible detention or imprisonment, but to see how they control everything, every minute of your life, and manipulate everything in the way they want.

Likewise, most of my Kurdish interviewees, whether on trial or not, describe their fear of the amalgamated forces of law and technology not as one of confinement in prison on the basis of evidence whose collection and interpretation seem outside their control, but of being relentlessly watched every moment of their lives. While Kurds certainly remain at the top of the Turkish state's hierarchy of risky subjects and categories of suspicion, the consciousness of surveillance is not limited to them, but has also spread to the Turkish activists that I interviewed. As one wellknown female activist from Istanbul noted, "We definitely come after Kurds in the state's list of usual suspects." Nevertheless, amalgamated force of law and technology seems to inspire a more pressing fear of imprisonment on the part of politicized non-Kurds than on Kurds themselves. Perhaps this because, as one doctoral student expressed it, "If you define yourself as a Kurd in this society and if you decide to struggle for your identity and language, you must be ready for imprisonment, death, and the loss of your future [...] It is a high-cost struggle." 
As one of the risks of technological surveillance for a surveilled body is the rewriting of its biography as a crime story, one of the ways people attempt to manage the experience is the production of a new daily language, addressing an unknown listener as well as the known receiver. This particularly affects conversations on the telephone, as telephone systems (mobile or wired) constitute what one former intelligence service agent described as the "main artery of the surveillance systems." The potential eavesdropper is always present, altering the very nature of daily language and distorting it into artificial forms. A journalist working for a pro-Kurdish news agency in Diyarbakır explained how consciousness of surveillance affects his daily communications:

All conversations are prolonged and became explanatory, even when it is not needed. I don't speak on the phone as I used to any more. I give full explanations about everything that I speak about on the phone. Not because the other does not get what I'm talking about, but to minimize the risk of manipulation of what I say by the constant guests on our line.

Thus, the amalgamation of the legal apparatus and technological intrusion generates collective desperation due to a felt loss of control over communication and meaning.

Ordinary language is not only instrumental and practical but also performative in the sense that nuances of meaning are captured and determined in the context of speech and diction. Thus, the amputation of language brings forth the felt loss of possibilities of language games, jokes, humor, irony and gossip, which make ordinary speech and daily conversation a dwelling place for human interaction (Wittgenstein, 2009). A primary school teacher in Diyarbakir tells me that he "cannot even gossip because, you know, all conversations are being read in courts. I mean the problem is not only that you have no privacy, no secrets any more, but also your relationships can be troubled." Technological representation thus has the potential to make the private public, and the coherent incoherent, or the innocent conversation a vehicle of other meanings in unpredict- able ways. The boundaries between private and public that prevent each invading the other evaporate.

In addition to the extra care they adopt in their daily speech on the phone or in particular places where they are sure of surveillance, most of my informants routinely clear the digital files in their computers, email 
inboxes, CDs and flash-disks, so as not to leave any material for surveillance regimes to manipulate. This, however, changes the very nature of the relationship between users and their machines, which are now means to control of communicability both by their users and the state. One female informant described this feeling:

My computer and my cellphone used to feel like the extensions of my body. Now I feel like there is someone else between my things and myself. I don't want to keep anything in my computer or my cell phone.

I have elsewhere explored the ways in which people in Turkey have grown attached to their digital devices, not only due to the machines' instrumental and display value, but also due to the seemingly liberating effects they can produce. In Turkey, users can employ these technologies to do things they normally cannot in in their daily lives and in existing social constraints. On the one hand, digital technologies enabled them to create a private world outside the monitoring of familial authority; a world where a desired self-design could be saved, deleted, or edited for user publics (Çelik, 2011) On the other, for the user counterpublic of Kurds, these technologies also allowed political mobilization for political protest through de-centralized text messages, or the dutiful and playful exercise of unfamiliar mother Kurdish language through texting among peers. Turkish-speaking public spaces were also transformed into Kurdish- speaking soundscapes through the ringtones of cellphones (Çelik, 2012).

Thus, the imposition of this new form of control on surveilled bodies who are conscious of their surveillance contributes to incommunicability in various ways. The main operations of this new form of power are the amputation of daily language, the shrinking of all public spaces of communication, and the distortion of the relationship between human beings and the machines that are both in the service of neo-liberal and authoritarian technological power yet also allow critical discourses, language, and counterpublics to form resistive potentialities. However, when the means of protecting oneself from this sort of power or of expressing oneself in any language inside or outside institutions or nonplaces seem to be lost, the motivation to use all non-places for resistance might increase. While Kurdish inmates started a hunger strike lasting 
approximately 70 days to demand Kurdish language rights in courts and education, and an end to the denial of the imprisoned PKK leader's right to communicate with his lawyers, the younger digital political bodies outside prisons continued their struggle, particularly to gain the means of communicability in digital spaces as well as in streets.

The production of the political in digital counterpublics

The recognition of limitations and inequalities that subsist in the virtual world and the potentialities that are immanent in the artificiality (the virtual self-design) of this non-place contribute to the "produsership" of activists. During the Arab Spring, activists made good use of digital communication technologies to organize prepare the ground for collective action against authoritarian state power, especially in Egypt through the forums, blogs and social media. Seeing this, Kurdish activists now seem to be more motivated to believe in the power of the Internet to effectively alter the political culture. Since the most pressing effect of the contemporary regimes of control is upon political individuals' communicative capabilities, the Internet becomes a means of creating a resistive possibility. In the hands of Kurdish users, including the Kurdish politicians, it has enabled the production of new and alternative communication platforms where political users ideally do not only voice their critiques, concerns, and demands, but also produce their own counterpublics, textual representations, and discourses to change the political and social landscape in which they live. A male activist in Diyarbakır recounts how he decided to start using digital technologies in his political struggle:

Ninety percent of Kurds write [on the net] with another persona, using proxies and so on. We know that we are not free in the virtual world either. We know that we are considered a threat. This is something transferred from the real world. It is like the political consciousness to desire not to decipher one's identity. It is the outcome of political reality, not fear. I have always been a regular user [...] I created characters for myself. So I thought, if I can create a character that becomes very popular on the net, I can do many other things there. This is how I did it, how I started using it for my own purposes.

Particularly against the existing forms of information monopoly and media synopticism, Kurds appropriate the virtual space to make their own news and share it with a larger public, preferably containing those unfamiliar with the Kurdish reality. 
News networks

News is central to the making of political culture in Turkey. As well as independent, pro-Kurdish, professional online news agencies such as ANF and DİHA, and web TV such as Nurce and IMC TV, there are many amateur news agencies, blogs, and social media. These are adopted by political activists to create an alternative news space that aims to have an effect on people's agenda and their decision making. For instance, the Uludere/Roboski case did not get coverage in mass media for some ten hours after the massacre due to the governmental pressure on media- scape. It was first announced in the pro-Kurdish news agencies, then spread to the social media (twitter and Facebook), and thousands of people were called for demonstrations against the massacre via de-centralized messages on the Internet. Most informants spoke about the resistive power of the Internet in terms of mobilizing collective action with reference to the protests against Uludere that were largely organ- ized through social media messages. One male university student from Istanbul commented on this:

We see how crucial these sites are for us in the Roboski example. People can only react to what is being done to us if they are informed about the truth. Roboski is not the first massacre of civilKurds, but it is the first one that many people became aware of, thanks to the Internet.

In the hands of Kurds, the Internet is also appropriated to build communities and to mobilize people for collective action whose targets exceed the organization of flash or political mobs. For instance, while the hunger strike of imprisoned Kurds did not find any coverage in the media or support from the wider public in the Turkish political landscape, some Kurdish netizens opened an account in Facebook called Açlık Postasl or The Hunger Post, which then turned into Ötekilerin Postast, or The Others' Post, a social network group active both in Facebook and Twitter. The groups aimed to make news, increase awareness about the strike, and support the strikers. The founder of Ötekilerin Postasl explains how they decided to create their Facebook group:

What the government has been doing is to silence all others. The mainstream media were contributing to this aim. We asked ourselves, why don't we create our own news network? Then, we began doing citizen journalism [on social networks]. We wanted to make objective news about the medical conditions of inmates that were on hunger 
strikes to inform their families and the larger public. We knew that there would be pressure from the state, but we have nevertheless continued.

As the founder of the network says, Açlık Postası became, unexpectedly, one of the most popular alternative news groups in a very short time. Through the virtual community of followers and contributors, they organized a campaign calling on people to withdraw money from their bank account and write "do not remain silent about the strikes" and put the money into ATM machines to make others engage with the discourses written on the banknotes. Along with this campaign, political netizens continued publishing photos of the strikers with provocative messages claiming to decipher the strikes and opening discussion sites to mobilize people to become supporters of the struggle of the strikers. In the end, when the strike became an undeniable issue in the political landscape, the government took action to communicate with the leader of PKK to make him stop the strike. The strike ended, and talks between the state and the PKK leader eventually restarted in January 2013. The group then relaunched as Ötekilerin Postası and continues to be followed by thousands of users, including not only Kurds but all others who have lost their trust in the mainstream media. Neither the Uludere protests nor the campaigns supporting the hunger strike are mere outcomes of a particular use of the Internet. However, these examples show how the virtual and the actual circulate and affect each other in the insurgent politics of Kurds and also others, especially when the state attempts to silence their voices, representations, language, and discursive practices through digital surveillance, media synopticism, and juridicial operations.

Resistance as a new form discourse: the "modern Kurdi perspective"

Kurdish users, and particularly the younger ones, also aim to present and develop a "modern Kurdi perspective," as some of my informants have put it, by way of the Internet. This perspective refers to a search for a new political subjectivity, discourse, and language that differs from traditional Kurdish discourse, while not breaking continuity with historical claims for cultural and political rights. As examples of political intervention that makes use of the net for modern Kurdi perspective, the 
collective called Kurd 2.0 controls different personas on social media (including Özgür Amed in Facebook, Özgür Gündem and bijwenist-Kurd 2.2 in Facebook and Twitter), urban-dictionaries (such as Tolaz), and amateur news agencies (such as Amed Ajans), as well as blogs/sites/ejournals (including Kurd 2.0). The founder of the collective explains their understanding of "new language" and "new discourse":

The typical Kurdish discourse was based on the language of the victim. We, Kurds, had tried to show that we existed in the first place, then we tried to show that we were dying. But there is no need for this. They already know what they did to us. It is crystal clear. What we need is real resistance. We need a new language to express ourselves. I perceive humor, irony, and sarcasm as the most effective tools of resistance to throw the fireball back to the ones who threw it at us. This is what Kurd 2.0 is about, as far as I am concerned.

Internet 2.0 here provides a new rationale for the social imagining of a new political subjectivity with its own discourse and language. Through such subjectivity, potentially all Kurdish users can become the producers of discourses to represent themselves in ways that challenge the typical representations of Kurds as a victimized group. Furthermore, this Kurdish digital activist defines Turkish as "a virus" or disease of Kurdish political subjectivity. Turkish operates not only as a language that the state obliges all citizens to speak, write, and receive schooling in, but also as a discourse which has affected the ways in which Kurds speak about themselves and represent their political subjectivity and claims, both in public and private spaces, and in both Kurdish and Turkish. The search for a new language and new perspective, which suggests a new political subjectivity that is framed as Kurd 2.0, is thus also a struggle to transgress the dominance of Turkish as a discourse (not merely as a language of everyday life and institutional practice). This dominance defines Kurdish language as a non-language, and imprisons the Kurds themselves in a discourse of backwardness, feudality, terrorism, armed rebellion, and provinciality, in which they must sacrifice their lives for the struggle of their cultural and ethnic identity. The mode of interaction and address, the form of the language of virtual exchange and discussion, and the particular brevity required in Facebook and Twitter that allows humor, laughter, and abusive messages to become easily viral 
and effective all contributes to the conceptualization of Kurd 2.0. This new political subjectivity thus proposes not only a new language but also a joy in political action.

A writer for Tolaz, a humorous Kurdi news network that is connected to the counterpublic of Kurd 2.0, expressed this as follows:

I was raised in a politically conscious family. But I was also assimilated, and cannot really read or speak in Kurdish. Living in Istanbul, I felt isolated from political discussions. The Internet has become a place for me to meet other Kurds. I was writing for the forums, dictionaries like Zitferheng. Then I came across the Kurd 2.0 [...] 2.0 means a lot to us. It is a new perspective, something more integrated into contemporary times. We speak about films, arts, and also politics. We believe that the language of politics needs to be lightened. We need to entertain ourselves as well. Politics should be joyful. The serious guys who are old and respected (kelli felli) are, like, boring. I respect them but I cannot really listen to them for so long [...] The use of humor mobilizes our target group as well. We criticize everything-KCK cases, T.C. [Türkiye Cumhuriyeti, the Turkish Republic] and Kurdish politics - but in our humorous way, which is more critical and effective in our opinion.

The Kurd 2.0 collective thus opens like a counterpublic that reaches both Kurdish and non-Kurdish users, particularly in social networks like Facebook and Twitter, addressing all with a critique posed against not only the dominant Turkish political culture that associates Kurdishness with threats to the unity of the country but also the dogmatic historical Kurdish politics that always asks the young agents to "sacrifice their life, love, and future," as one young female informant expressed it. The desire to elaborate textual strategies of selfhood that initiate new signs of identity and create innovative sites of collaboration, negotiation, and contestation is common to all politically aware users of the net, regardless of their links to the Kurd 2.0 collective. The "light" and sarcastic language and the joyful mode of address is not less political in their eyes, but is rather the most effective one. One $\mathrm{PhD}$ student explained that it was his encounters with the "white-democrat Turk" while writing in Ekşisözlük (a popular urban dictionary site) that made him "search for new means of argumentation to challenge their memorized discourses about the Kurdish movement." In doing so, he explains, "I also began to acknowledge that the way we make our language and define ourselves have to change." The encounter with others in the flow of 
messages within the social laboratory of the net, Kurds and non-Kurds alike, motivate and provoke users to shatter the dichotomous thinking of many people in Turkey. This destabilizes fixed political identities such as Turk/Kurd, terrorist/pacifist, modern Turks/traditional Kurds have distinct languages, discourses, and terminologies which rely on remaining explanatory, serious, and exclusive.

For instance, one female law student from İstanbul said that she puts images of female guerrillas on her Facebook wall where she enjoys the "shock" of her Turkish Facebook friends and shows them the "absurdities of seeing the ones on the mountains as monsters." While most of the young female activists appreciate the Kurdish movement for its struggle to liberate the Kurdish women from traditional patriarchal norms, they also criticize the authoritarianism of the movement and of the dominant Kurdish culture, with its greater pressure on unprivileged gender positions. A medical student in Istanbul explained:

I am Zaza. A Woman. A believer. And I will not deny that I have had sympathy for both the cemaat [The Fethullah Movement] and for the party [PKK] at different times of my life [...] But, however I define myself, I am told what I have to do. I am really fed up with this. I just want to be a human being who has a conscience.

She says her Facebook wall and her posts in various different digital communities always intend to "surprise" the ones who cling to fixed identities, excluding what remains outside. At times, then, the self-creations of users in the social laboratory of virtual communities become an expression of the multitude or of the multiplicity that resists the commands of power regimes to homogenization and standardization.

In a similar vein, a transsexual woman living in Diyarbakır who created a Kurdish Lesbian, Gay, Bisexual, and Transgender (LGBT) network (Hebun) on Facebook and built a community out of silenced Kurdish LBGTs living in different areas in Turkey, explained:

We are struggling for our ethnic identities and also our sexual identities [...] We're struggling against the Turkish nationalists who deny the rights of Kurds and macho Kurds who deny the rights of LGBTs and also bourgeois Turkish LBGTs who always speak in terms and concepts that ordinary people don't understand.

Or from totally different perspective, one nationalist conservative activist (IBH) became popular in the offline Kurdish political landscape after 
his presence attracted thousands of followers in Facebook. He is also involved in polemical discussions with Kurd 2.0. As he explained:

We need a theoretical, intellectual basis for our movement founded upon our history. My followers and I are having intellectual discussions about ourselves and our identity. We should be able to define ourselves through our self-determination as a nation, but this should not be exclusive of our religious identities, nor of our history and traditions.

The digital counterpublics formed by these Kurds aim to reach both Kurdish political agents and others to re-form themselves and their languages through exchange and discussion. They are attempts to challenge the dominant culture and power - be it state power, the official discourse of the Turkish authorities as internalized by Turkish nationalists, PKK doctrines, or patriarchal language that consigns women or alternative sexual identities to unprivileged positions. As one male user from Diyarbakır said:

All of us are searching for a Kurdi perspective, Kurdi discourse, Kurdi language in everything we say [...] It's like we're integrated into the contemporary era, but we are not assimilated [...] We even criticize some notions and approaches of the movement, but not with the language of T.C. or the state.

In this regard, these digital communities attempt to generate a modern Kurdi perspective as a discursive event. While this perspective is always already related to the political and ethnic struggle being carried out through armed struggle and parliamentary participation, it is also radically different from them in the way it operates. A modern Kurdi perspective seek to produce an ever new language and discourse, accommodate laughter and joy, be fluid and inclusive of all oppositional subject positions, remain critical of any form of authority, and articulate a distinctive design and aesthetics in the digital mediascape and creative/ cultural industries. In other words, they are striving to produce a new means and mode of "the political" as state power adopts new pacification regimes to tame their communicative and cognitive capacities.

While informants did not consider digital activism a form of political action able to bring "revolution" to the region by itself, all of them considered the discursive potentialities of the Internet to be significant. As Radikal Öğretmen (his Facebook persona) put it, the Internet is "one 
of the essential sites of contemporary political movements that aim to mobilize young people." Or again, as a cafe co-owner in Diyarbakır in his late 20s stated, digital activism is "something that shows that technologies are not only in the service of the state, but also that of the people."

\section{Conclusion}

This research has attempted to explore both forms of control by Turkish state resistance to them by Kurds that make use of digital information technologies. Over the last couple of years, not only Kurdish political subjects but also other dissident agents of Turkey have been feeling increased pressure of freedom of information and speech. For Kurds, the amalgamation of the forces of law and technology on their bodies, strengthened by mass-media representations, have amputated the possibilities of ordinary language, representation, and discourse. Post-structuralist theories in particular inform us that it is language that initiates subjectivity. Through attempts to destroy the possibilities of language-historically on the mother language itself and currently on modes of expression in all languages the Kurds and their surveillors use - the state attempts to colonize Kurds political bodies, their subjectivities, and their communicative capabilities.

I consider the digital activism of Kurds as an attempt to regain agency in meaning production, retrieve the political body, and reconstruct language as a means of speech and discourse through which they can represent themselves and their self-presence. As most of my informants underlined repeatedly, Internet activism is only relevant until someone pulls the plug. Yet, until that moment, it functions as a space for communicative possibilities that might have an impact on real life. The Kurds, for whom both public and private spaces of speech and diction have shrunk due to the prevalent surveillance, have created a counterpublic through which they reach out to others and recreate themselves in exchange and discussion in the virtual, non-space of the net. The political Kurds, particularly young ones, appropriate the Internet to transform both political language and traditionally instituted political subjectivities and the dominant political culture that constitutes them as unprivileged citizens of Turkey in need of pacification. As cyborgs, simians, or produsers living, communicating, and producing in a digital ecology, they know how to evade filtering systems to meet and reach non-Kurds in the digital mediascape. They are political. Their daily digital struggle is a cultural and political one that cannot be dissociated from historical, insurgent Kurdish politics which aims for language and education rights. Yet, the way they produce the political is radically different from 
their elders or from those involved in traditional forms of political struggle. They take politics seriously, but the language they use enjoys the possibilities of humor, laughter, and sarcasm. They value political struggle as an essential part of their subjectivity, but question the call to sacrifice their lives, youth, and love to it. They are also the counterpublic of the new pacification regimes that make use of fluid systems to control economic, social, and political forces.

This research also touches on the whys and wherefores of the Gezi Revolt of 2013. These nationwide protests were historic, bringing young people together with different social classes with different socio-cultural and political perspectives, and generating the collective will to end state authoritarianism. The authoritarianism that I attempted to outline here is enacted on the Kurdish movement using all the means of technological surveillance and imperial power regimes of the global networks. Middle class urbanite young people are often criticized by their elders as an apolitical digital generation. Yet the digital activism of the young Kurds demonstrates the ways in which young people can appropriate the social media and the streets to produce new means and modes of "the political." As the digital counterpublics of the Kurds did before them, the Gezi protesters have used the digital mediascape to change Turkey's political landscape to one in which their voices matter and where they can see, hear, and speak with each other across conventional social and identity boundaries. And again, as Kurdish activists have, The Gezi protesters have adopted the digital mediascape which they inhabit on daily basis to create their own political language and subjectivity, generating joy in political action, the humorous power of political discourse, and asserting their agency to make their own decisions about their lives, environment, and discourses. The Gezi Protests have been momentous precisely in the moments when the protesters have grown conscious that other groups have been victimized by the authoritarian regime of the state in the same way they experienced, including media synopticism and police brutality. One such moment was when a twitter user wrote to Bijwenist-Kurd 2.0: "I am so ashamed of my own fascist attitude towards you. I now understand what you have been through with this corrupted media." Another wrote "I apologize to you my friends. We have been following the Kurdish problem through this media. We've been stupid. A big apology"(Çelik, 2013). In such instances, the "modern Kurdi perspective" that produces and is pro- duced by the Kurds' digital counterpublics reaps its own rewards. Much 
will now depend on how far the counterpublic can be extended, and the extent to which it transforms its members' identities and language, and raises their political consciousness of the sheer possibility of resistance.

\section{References}

Alexa.com. www.alexa.com/topsites/countries/TR.

Arslantaş-Toktaş, Selma, et al. Türkiye'de Dijital Gözetim: T.C. Kimlik Kartlarından E-Kimlik Kartlarına Yurttaşın Sayısal Bedenlenişi. İstanbul: Alternatif Bilişim Derneği, 2012.

Ayata, Bilgin. "Kurdish Transnational Politics and Turkey's Changing Kurdish Policy: The Journey of Kurdish Broadcasting from Europe to Turkey.” Journal of Contemporary European Studies 19, no. 4 (2011): 523-533.

Ball, Kirstie. "Organization, Surveillance and the Body: Towards a Politics of Resistance." Organization 12, no. 1 (2005): 89-108.

Best, Kirsty "Living in the Control Society: Surveillance, Users and Digital Screen Technologies." International Journal of Cultural Studies 13, no. 5 (2010): 5-24.

Bogard, William. "The Coils of a Serpent: Haptic Space and Control Societies," C Theory (2007). http:// www.ctheory.net/articles.aspx?id=581.

Bora, Tanıl and Selçuk Kozağaçlı. "Çağdaş Hukukçular Derneği Başkanı Selçuk Kozağaçlı ile söyleşi: 'Elastik ve yapışkan bir ağ'.’ Birikim 273 (2012): 34-38.

Çelik, Burçe. "The Revolt of the Diverse Youth and the Production of the Political." opendemocracy.net, http://www.opendemocracy.net/burce-celik/diverse-revolt-of-turkish-youth-and-production-ofpolitical.

—. "Appropriation of Cell Phones by Kurds: The Social Practice of Struggle for Political Identities in Turkey." In The Mobile Media Reader, edited by Noah Arceneaux and Anandam. Kavoori, 163-72. New York: Peter Lang, 2012.

- Technology and National Identity in Turkey: Mobile Communications and the Evolution of a PostOttaman Nation. London: I.B. Tauris, 2011.

Deleuze, Gilles. "Postscript on the Societies of Control." OCTOBER 59 (1992): 3-7.

Della Porta, Donatella. "Multiple Belongings, Tolerant Identities and the Construction of 'Another Politics': Between the European Social Forum and the Local Social Fora." In Transnational Protest and Global Activism, edited by D. Della Porta, and S. Tarrow, 175-203. Lanham: Rowman and Littlefield, 2005.

European Commission. Turkey 2012 Progress Report. http://ec.europa.eu/enlargement/pdf/key_ documents/2012/package/tr_rapport_2012_en.pdf.

Fenton, Natalie. "Contesting Global Capital, New Media, Solidarity and the Role of a Social Imaginary." In Reclaiming the Media, edited by N. Carpentier, and B. Cammaerts, 225-42. London: Intellect, 2008.

Foucault, Michel. Discipline and Punish. New York: Vintage, 1977.

Gambetti, Zeynep. "The Spatial Dynamics of the Kurdish and Zapatista Movements." New Perspective on Turkey 49 (2009): 43-64.

Grinnel, Claudia, K. "From Consumer to Prosumer to Produser: Who Keeps Shifting My Paradigm? (We Do!)" Public Culture 21, no. 2 (2009): 577- 589.

Groys, Boris. "Obligation to Self-Design," e-flux 11 (2008). http://www.e-flux.com/journal/the-obligationto-self-design.

Haggerty, Kevin and Richard Ericson. "The Surveillant Assemblage.” In The Surveillance Studies Reader, edited by Sean Hier and Joshua Greenberg, 104-16. New York: Open University Press, 2007.

Hardt, Michael and Antonio Negri. Empire. London: Harvard University Press, 2000.

Hassanpour, Amin. "Satellite Footprints as National Borders: MED-TV and the Extraterritoriality of State Sovereignty.” Journal of Muslim Minority Affairs 18, no. 1 (1998): 53-72.

Hürriyet Daily News. "No hunger strikes says PM amid rallies." Accessed January 4, 2013. http://www. hurriyetdailynews.com/no-hunger-strikes-says-pm-amid-rallies.aspx?pageID=238\&nid=33710

Kirişçi, Kemal. The Future of Turkish Foreign Policy. İstanbul: Boğaziçi University Press, 2004.

Lyon, David. "Surveillence Technology and Surveillance Society." In Modernity and Technology, edited by Thomas J. Misa, Philip Brey, and Andrew Feenberg, 170-84. Cambridge: MIT Press, 2004. 
. "Resisting Surveillance." In The Surveillance Studies Reader, edited by Sean Hier, and Joshua Greenberg, 368-77. New York: Open University Press, 2007.

Marx, Gary. "What's New about the "New Surveillance'? Classifying for Change and Continuity." In The Surveillance Studies Reader, edited by Sean Hier, and Joshua Greenberg, 83-94. New York: Open University Press, 2007.

Masoud, Tarek. "The Road to (and From) Liberation Square.” Journal of Democracy 22, no. 3 (2011): 20-34.

Mathiesen, Thomas. "The Viewer Society: Michel Foucault's Panopticon Revisited." Theoretical Criminology 1, no. 2 (1997): 215-34

Morozov, Evgeny. The Net Delusion: The Dark Side of Internet Freedom. New York: Public Affairs, 2011.

Nebeyah, Stephanie. “Turkey Using anti-Terrorism Law to Quash Debate: U.N.” Reuters. Accessed January 5, 2013. http://www.reuters.com/article/2012/11/01/us-turkey-un-rights-idUSBRE8A012020121101

Özoğur, Hakan. Kurdish Notables and the Ottoman State. New York: NYU Press, 2004.

Poster, Mark. The Mode of Information. Chicago: University of Chicago Press, 1990.

Romano, David. "Modern Communication Technology in Ethnic Nationalist Hands: The Case of the Kurds." Canadian Journal of Political Science 35, no. 1 (2002): 127- 49.

Reporters Without Borders. "Turkey: The World's Biggest Prison for Journalists.” https://en.rsf.org/turkeyturkey-world-s-biggest-prison-for-19-12-2012,43816.html.

Sheridan, David, Jim Ridolfo, and Anthony J. Michel. The Available Means of Persuasion: Mapping a Theory and Pedagogy of Multimodal Public Theory (New Media Theory). Anderson SC: Parlor Press, 2012.

Sofia, Zoe. “Container Technologies.” Hypatia 15, no.2 (2000): 181- 201.

Stone, Allucquere Rosanne. The War of Desire and Technology at the Close of the Mechanical Age. Massachusetts: MIT Press, 1996.

Topal, Çağatay. "Global Citizens and Local Powers: Surveillance in Turkey.” Social Text 83, no. 2 (2005): 85-93.

Tüfekçi, Zeynep, and Wilson, Christopher. "Social Media and the Decision to Participate in Political Protest: Observations from Tahrir Square.” Journal of Communications 62 (2012): 363-379.

Warner, Michael. "Publics and Countepublics." Public Culture 14, no.1 (2002): 49-90.

Wittgenstein, Ludwig. Philosophical Investigations. Oxford: Blackwell-Wiley, 2009.

Yeğen, Mesut. "The Kurdish Question in Turkish State Discourse." Journal of Contemporary History, vol. 34 (1999): 555-68

. "The New Kurdish Movie.” Jadaliyya. http://www.jadaliyya.com/pages/index/3242/the-new-kurdishmovie 